\title{
PERUBAHAN PERILAKU REMAJA HINDU DALAM MENJALANKAN AKTIVITAS KEAGAMAAN DI KOTA DENPASAR
}

\author{
Oleh : \\ I Nyoman Temon Astawa \\ email : temonastawa@gmail.com
}

\begin{abstract}
Abstrak
Faktor-faktor yang mempengaruhi perubahan perilaku remaja Hindu dalam aktivitas keagamaan di Kota Denpasar adalah faktor internal dan faktor eksternal. Faktor internal yaitu perkembangan pikiran dan perkembangan biologis, sedangkan faktor eksternal yaitu lingkungan sekolah dan lingkungan keluarga. Kedua faktor tersebut dapat mempengaruhi perilaku remaja dalam aktivitas keagamaan di Kota Denpasar. Perubahan tersebut merupakan perubahan yang terjadi pada perilaku remaja Hindu dalam menjalankan aktivitas keagamaannya ke arah yang lebih baik karena sebagian besar siswa masih mengikuti aktivitas-aktivitas keagamaan yang diselenggarakan di sekolah, keluarga maupun masyarakat.
\end{abstract}

Kata Kunci : Perilaku Remaja Hindu, Aktivitas Keagamaan.

\section{Abstract}

Factors influencing behavior change of Hindu adolescent in religious activity in Denpasar City are internal factor and external factor. Internal factors are the development of mind and biological development, while external factors are school environment and family environment. Both of these factors can affect the behavior of adolescents in religious activities in the city of Denpasar. The change is a change that occurs in the behavior of Hindu adolescents in running their religious activities in a better direction because most students still follow religious activities held in schools, families and communities.

\section{PENDAHULUAN}

Perkembangan ilmu pengetahuan dan teknologi yang pesat dewasa ini memiliki pengaruh besar terhadap berbagai bidang kehidupan masyarakat. Kemajuan ilmu pengetahuan dan teknologi berdampak semakin dinamis gerak perubahan baik fisik dan non fisik berbagai sektor kehidupan yakni ideologi, politik, ekonomi, sosial budaya, pertahanan dan keamanan.

Di bidang ideologi sudah dapat dirasakan keragu-raguan terhadap ideologi Pancasila yang telah teruji sebagai pandangan hidup bangsa semenjak dilahirkan sebagai ideologi tunggal di negara Indonesia. Sebagai bangsa Indonesia yang menghormati jasa para pahlawan sebenarnya sudah tidak terdapat ruang dan waktu untuk membicarakan ideologi lain sebagai pandangan hidup bangsa. Sesungguhnya bangsa Indonesia sudah berada pada kondisi yang final terhadap masalah ideologi bangsa, namun secara formal maupun non formal masih merupakan suatu perjuangan yang gigih dari kelompok 
tertentu untuk menggantikan ideologi Pancasila itu dengan ideologi yang lain.

Pembangunan politik di Indonesia dewasa ini perlu mendapat perhatian dari berbagai kalangan secara lebih mendalam. Perioda reformasi membawa perubahan yang cukup besar terhadap kehidupan berpolitik di negara kita. Pada era orde lama dengan sistem parlementer dan multi partai mengakibatkan kabinet jatuh bangun tidak dapat menciptakan situasi yang stabil untuk membangun negeri ini. Partai ketika itu menjamur sehingga situasi pembangunan khususnya di bidang politik kurang kondusif.

Berbeda pada jaman orde baru kehidupan bernegara khususnya dalam bidang politik mulai disempurnakan dengan mengurangi jumlah partai politik melalui menfungsikan sesuai aliran ideologi masing-masing. Organisasi kepartaian sebagai penopang kehidupan berpolitik diciutkan menjadi tiga partai dan sistem kendalinya terpusat pada elit partai tertinggi yaitu pada dewan penasehat. Fenomena ini bertahan cukup lama sehingga terjadi tatanan pembangunan yang sentralistik. Daerah-daerah bawahan dikoordinasikan dari pusat secara aturan yang ditentukan oleh pusat. Implikasinya sebagian besar tokohtokoh yang lahir sebagai pemimpin dikehendaki oleh pusat yang menjadi sentra pengendali kehidupan perpolitikan di Indonesia untuk mendukung kekuatan kehidupan berpolitik. Generasi muda dari berbagai golongan dikelompokan menjadi tiga kelompok besar dalam bentuk organisasi pemuda underbaw dari aliran kepartaian masing-masing. Seorang pemimpin organisasi kepemudaan akan eksis ketika loyalitas yang ditunjukan mengakar pada pemimpin tertinggi pemerintahan formal. Pemuda yang lahir sebagai pemimpin organisasinya berasal dari selera pusat atau atasan.

Dibidang ekonomi masih berada pada angka pengangguran dan kemiskinan yang memperihatinkan. Pengangguran berkisar enam juta jiwa dan angka kemiskinan kurang lebih 40 juta jiwa. Pembangunan ekonomi belum sepenuhnya bangkit dari keterpurukan dan guncangan krisis moneter yang dimulai sekitar tahun 1997. Sudah hampir sebelas tahun berlangsung krisis ekonomi di Indonesia belum juga dapat memenuhi apa yang menjadi harapan bersama berupa perbaikan ekonomi belum banyak kemajuannya. Berdasarkan infomasi dari berbagai media masa baik media cetak maupun elektronik beberapa negara yang mengalami krisi moneter pada era yang sama sudah bangkit dari resesi yang dialaminya. Negara tetangga Thailand misalnya hanya delapan tahun sudah kembali pulih ekonominya, sedangkan Indonesia masih terpuruk jauh dari pemulihan krisis sebagaimana menjadi harapan bersama. Pertumbuhan ekonomi masih rendah, di bawah tujuh persen pertahun, berdampak pada lambatnya penyerapan tenaga kerja sehingga kesejahteraan penduduk masih relatif rendah karena perkapitanya masih jauh di bawah standar.

Kehidupan sosial budaya bangsa Indonesia masih didominasi oleh sikap mental yang konsumtif dan materialistis. Budaya yang jelek masih secara objektif dalam kehidupan bermasyarakat dan bernegara di era sekarang ada serta berkembang dalam jaringan yang kuat mengakar secara luas seperti korupsi, kolusi, nepotisme, dan kehidupan madat dengan 
menkonsumsi obat terlarang semakin marak. Budaya korupsi misalnya pada era otonomi daerah sekarang bergeser menjadi di daerah-daerah yang lebih rendah bahkan dengan sistem jaringan yang rapi dan masuk pada berbagai sektor pelayanan publik. Pengelolaan pembangunan di daerah-daerah ada kecenderungan memanfaatkan kelompok-kelompok tertentu yang memiliki akses yang kuat dan kedekatan dengan para tokoh dan politisi sehingga dapat mempengaruhi suatu kebijakan. Penyalahgunaan wewenang dan jabatan kerap terjadi bahkan fenomenanya semakin mengabaikan rambu-rambu hukum yang telah ada.

Kehidupan generasi muda terutama para remaja sudah banyak terlibat pada penyalahgunaan obat terlarang yang disebut psikotropika dan penyebarannya sudah sampai pada wilayah pedesaan yang jauh dari kota. Anak-anak muda sudah terbiasa dengan kehidupan minuman keras yang memabukkan dan terlibat sebagai pemakai narkoba bahkan menjadi pengedar jaringan perdagangan obat terlarang itu. Tentu salah jika membiarkan situasi yang demikian merosot cendrung mengabaikan nilainilai kehidupan yang mulia dan mulai tidak memperhatikan norma-norma moral sehingga terjadi perubahan orientasi perilaku remaja terhadap aktivitas keagamaan Hindu. Hal ini perlu segera mendapat perhatian dari berbagai pihak.

Ketika menengok dan merenungkan sejarah perjuangan para pendahulu yang gugur menjadi kusuma bangsa, semestinya ada muncul kesadaran yang menggugah generasi muda untuk menata kehidupan yang lebih baik. Sebenarnya belum terlambat karena masih ada kesempatan yang lebar untuk berbenah diri menuju kemajuan bersama dalam kehidupan berbangsa dan bernegara. Para pemuda khususnya para remaja merupakan generasi penerus yang dapat memperbaiki keadaan menjadi lebih baik. Para remaja memiliki kemampuan yang cukup masih tersimpan dalam merubah keterpurukan yang dialami sekarang. Kaum remaja adalah sekelompok individu yang masih kuat untuk dapat berjuang mengisi kemerdekaan yang telah diwariskan ini. Suatu hal yang keliru jika para remaja tidak tergugah hatinya untuk berjuang menjadi para pemimpin negeri ini yang cerdas dan mengurangi beban bangsa ini yang sudah cukup sarat.

Dalam kaitan dengan bidang pertahanan dan keamanan sudah perlu dilakukan perubahan yang cukup mendasar pula. Pertahanan ke dalam negeri sesungguhnya yang layak diberikan perhatian yang lebih serius karena dewasa ini dari kalangan kelompok rakyat kecil yang dikenal dengan istilah grass root atau masyarakat bawah merasa kurang memiliki negeri ini. Adalah suatu yang wajar dirasakan ketika secara teoretis dan yuridis individu-individu merasa tidak dilindungi oleh negara dalam hidupnya sehari-hari. Secara legal formal perangkat hukumnya sudah ada kenyataannya dapat dilihat dengan mata sendiri banyak anak tidak menikmati pendidikan yang semestinya mereka peroleh. Sehingga mereka hidup terpaksa menjadi anakanak jalanan dan banyak orang-orang yang terlantar belum mendapat penanganan yang semestinya menurut hukum dan peraturan yang semestinya dibuat untuk melindunginya. Jika rakyat sudah hidup melarat dan terjebak dalam kemiskinan daya tahan suatu bangsa akan menjadi lemah baik 
dalam bidang sosial budaya dan pertahanan. Inilah sesungguhnya ancaman yang terburuk yang menghadang.

Bagi seorang remaja diharapkan mulai sejak dini berusaha untuk memiliki pengetahuan yang cukup tentang kemasyarakatan misalnya sejarah, hukum, ekonomi, kebudayaan, politik dan lain-lain. Penguasan pengetahuan yang banyak akan menjadi bekal baginya untuk hidup dan berkembang di masyarakat (Willis, 2008 : 13). Sebagai manusia yang sedang mengalami perkembangan dengan keadaan memasuki perkembangan psikologis yang pancaroba perlu mempunyai suatu pegangan yang kokoh terhadap nilai-nilai moral, etika yang baik karena nilai-nilai tersebut dapat menyelamatkan perkembangan kehidupannya dikemudian hari.

Berbagai media telah banyak mempengaruhi kehidupan remaja sekarang. Remaja sebagai generasi muda memiliki kekuatan budaya yang semakin meningkat hal ini dapat dibuktikan bahwa sebenarnya sesuatu yang menarik bagi anak muda tidak seluruhnya negatif, masih banyak nilai yang bermanfaat dapat mereka lakukan di masyarakat.

Roger (2007 : 16), pada saat ini remaja adalah penduduk yang di caricari, bukan menjadi sebuah renungan di televisi saja dan sesungguhnya mereka sudah menjadi bagian dari jaringan penyiaran oleh lembagalembaga penyiaran internasional seperti Nickelodeon's the $\mathrm{N}$ dan Disney Channel sejak tahun 1990-an.

Beberapa ahli media seperti Shid Gibbons (dalam Roger, 2007 : 87) mengatakan bahwa sekolah adalah panggung yang paling utama dalam usaha untuk mendapatkan popularitas dan menggaet pacar, namun sekolah masih banyak hanya untuk arena bersosialisasi.

Sebenarnya sekolah bagi para remaja adalah suatu arena mendapat nilai prestasi akademik yang tinggi, memantapkan kesadaran bela negara, atau merupakan suatu arena untuk menumbuhkan intelektualitas para remaja.

\section{PEMBAHASAN}

Sejumlah siswa sebagai salah satu kelompok remaja telah mengalami suatu pergeseran perilaku keagamaannya ada kecenderungan mengarah pada kesemarakan keagamaan tetapi tidak mencerminkan nilai-nilai keagamaan yang dianutnya. tulisan ini mencoba menggali tentang prilaku remaja tersebut berkaitan dengan aktivitas keagamaannya. Adapun faktor-faktor yang menyebabkan terjadinya perubahan tersebut diantaranya.

\section{Faktor Internal}

Pada pembahasan ini fokus pembicaraan yang menjadi inti dari suatu pembahasan yaitu faktor internal siswa sebagai remaja Hindu. Sebagaimana mestinya remaja sebagai manusia mengalami perkembangan sesuai dengan perkembangan sebagai manusia. Di Kota Denpasar sebagai salah satu kota yang memiliki sekolah unggulan terdapat kopetensi-kopetensi yang cukup ketat untuk dimiliki oleh remaja secara realitas kondisi ini sesuai dengan perkembangannya telah mengalami perubahan orientasi perilaku terhadap aktivitas keagamaan sebagaimana yang disebutkan dalam teori perkembangan dari seorang tokoh yang terkenal Willhelm Wundt (dalam Achir 1980 : 13) dengan teori Gestalt menyatakan bahwa perkembangan tersebut bersifat global. Maksudnya adalah perkembangan itu 
terjadi secara menyeluruh, samarsamar, semakin lama semakin jelas bagian-bagian yang berkembang. Perkembangan bersifat totalitas, mengikuti hukum-hukum perkembangan kesatuan organ.

Tubuh manusia terdiri atas pikiran, perasaan, panca indera, dan badan jasmani. Sesuai dengan teori perkembangan yang dikenal dengan teori Gestal maka ada beberapa faktor internal siswa yang memberikan pengaruh. Menurut Panuju (1999 : 71) bahwa faktor internal yang juga dikenal dengan faktor endogen adalah faktor yang mempengaruhi proses perkembangan remaja karena adanya pembawaan sejak saat kelahiran. Terdapat dua faktor internal atau endogen yaitu : 1) faktor endogen individual meliputi semua sifat, bakat, kemampuan dalam bentuk potensi, proses perkembangan dan kecepatannya ditentukan oleh susunan gen (pembawaan keturunan), 2) faktor endogen umum yang bersifat ontologis dan individual adalah faktor kematangan. Adapun faktor-faktor internal tersebut dapat diuraikan sebagai berikut :

\section{Perkembangan Pikiran}

Panuju (1999 : 116) menyatakan remaja memiliki perkembangan mental ke arah berpikir yang logis serta dapat mempengaruhi pandangan dan kepercayaan kepada Tuhan, mereka tidak dapat melupakan Tuhan dari segala peristiwa yang terjadi di alam ini. Bila mereka telah meyakini bahwa Tuhan itu maha kuasa, maha pengatur, dan dapat mengendalikan alam ini maka segala apapun yang terjadi, baik peristiwa alam maupun peristiwa sosial, dan hubungannya dengan masyarakat akan dilimpahkan kepada Tuhan tanggungjawabnya.

Remaja pada umumnya memiliki pikiran yang belum stabil. Orientasi remaja cenderung kepada kulit luar bukan pada inti atau makna yang ada di dalam proses aktivitas keagamaan Hindu. Para remaja di Kota Denpasar telah mengalami perubahan perilaku terhadap aktivitas keagamaan.

Ada beberapa faktor internal remaja yang mempengaruhi perubahan orientasi perilaku remaja terhadap aktivitas keagamaan. Faktor-faktor internal remaja tersebut meliputi bakat sejak lahir, minat terhadap orientasi perilaku terhadap aktivitas keagamaan yang baik selain itu kematangan emosional juga salah satu faktor yang dapat mempengaruhi remaja untuk selalu memiliki orientasi perilaku yang baik terhadap aktivitas keagamaan di Kota Denpasar.

\section{Perkembangan Biologis}

Perubahan cepat yang terjadi pada tubuh remaja akan diikuti oleh dorongan-dorongan yang kadangkadang berlawanan dengan nilai-nilai yang pernah di dapatinya, baik dari orang tua maupun dari para gurunya. Akibatnya mulai ada kecenderungan menghayal dan menyukai jenis lain (Panuju,2005 : 149).

Pada bagian lain muncul dalam diri remaja berbagai keguncangan yang berkecambuk dalam dirinya itu, menyebabkan semakin tidak tenang, gelisah cemas, marah, sedih dan lain sebagainya. Kepercayaannya kepada Tuhan kadang-kadang terganggu, sifat-sifat Tuhan diragukannya, sehingga menimbulkan perilaku ambivalensi beragama, cirinya kadang-kadang ia sangat rajin beribadah, kadangkadang mogok dan lalai, perilakunya seolah-olah tidak percaya dengan keberadaan Tuhan (Panuju, 2005 : 149-150).

Para remaja yang juga adalah 
siswa Hindu di Kota Denpasar mengalami dorongan sebagaimana diuraikan di atas. Menurut data yang diperoleh adalah siswa sebagai remaja Hindu banyak mendapat dorongan dari perkembangan tubuh atau biologisnya. Terhadap aktivitas keagamaan siswa memang menampakkan kecenderungan yang ambivalensi yaitu kadang-kadang rajin sembahyang, kadang-kadang mogok. Sikapnya terhadap keyakinannya sering berubah, namun berkat bimbingan guru, perubahan orientasi perilaku remaja tidak jauh berubah terhadap nilai-nilai agama dalam aktivitas keagamaan Hindu di ini.

Berdasarkan uraian di atas maka sesungguhnya perubahan orientasi perilaku remaja Hindu terhadap aktivitas agama Hindu di Kota Denpasar mengalami suatu perubahan dengan adanya perkembangan biologis yang cepat pada usia memasuki remaja.

\section{Faktor Eksternal Siswa}

Panuju (1999 : 73) menyatakan faktor eksogen / eksternal dapat dibagi menjadi tiga bagian yaitu :

1) faktor lingkungan (enveroment) : lingkungan di sekitar individu meliputi keluarga dan sosial.

2) Makanan mempengaruhi perkembangan fisik dan penampilannya, secara khusus pada masa remaja kebutuhan makanan meningkat sesuai dengan pertumbuhan fisiknya.

3) Belajar adalah merupakan faktor eksternal yang dapat mempengaruhi perkembangan remaja.

Bagi remaja menurut Panuju (1999: 75) menyatakan bahwa belajar yang sistematis dipersiapkan tergantung dari banyak faktor antara lain : faktor pengalaman, dan faktor kesempatan yang semakin luas.
Perubahan perilaku remaja di samping disebabkan oleh faktor internal remaja juga ada faktor eksternal yang mendorong perubahan perilaku tersebut. Faktor-faktor eksternal yang mendorong perubahan orientasi perilaku remaja di Kota Denpasar dapat diuraikan dalam bagian berikut.

\section{Lingkungan Sekolah}

Kota Denpasar yang memiliki sekolah unggulan dan sekolah pavorit lainnya baik itu tingkat menengah atas dan meneghah pertama, tentunya memiliki sarana dan prasarana pembelajaran yang memadai khususnya dalam bidang keagamaan sehingga aktivitas keagamaan dapat berjalan dengan baik. Dengan kondisi yang demikian maka para remaja Hindu memiliki orientasi perilaku terhadap aktivitas keagamaan yang baik dapat di lihat pada penyelenggaraan kegiatan keagamaannya sangat semarak. Data yang didapat diantaranya dari remaja adalah :

"Kami remaja di Kota Denpasar dari salah satu sekolah unggulan memiliki sarana dan prasarana yang tersedia memadai. Dalam bidang aktivitas keagamaan misalnya berjalan sesuai dengan yang diharapkan sehingga sekolah memfasilitasi kegiatan keagamaan anak-anak. Sampai sekarang siswa masih semarak dan yakin bahwa aktivitas keagamaan sangat bermanfaat karena memang kami selalu berusaha untuk itu. Sehingga para remaja di sekolah perubahan orientasi perilakunya mendukung aktivitas keagamaan Hindu di sekolah seperti dalam pelaksanaan mecaru, melaspas sekolah, siswa sebagai remaja 
terlibat dengan antusias, demikian juga pada penyelenggaraan adalah Saraswati di sekolah."

Berdasarkan uraian data di atas maka perubahan orientasi remaja Hindu di Kota Denpasar terhadap aktivitas keagamaan di sekolah masih tetap yakin bahwa aktivitas keagamaan seperti odalan Saraswati, mecaru, melaspas sekolah masih aktif diikuti oleh siswa sebagai bukti bahwa para remaja Hindu di Kota Denpasar didorong oleh lembaga pendidikannya untuk menjalankan aktivitas agama Hindu dengan baik di sekolah maupun di luar sekolah.

\section{Lingkungan Keluarga}

Lingkungan keluarga berpengaruh untuk memberikan dorongan terhadap perilaku remaja, misalnya kasih sayang yang diberikan orang tua berupa hubungan emosional yang akrab akan menimbulkan rasa aman pada diri anak (Willis, 2005 : 131).

Frend (dalam Willis, 2005 : 131) menyatakan kasih sayang diberikan orang tua kepada anak-anaknya sejak dini atau sejak kecil, dapat membentuk kata hati yang oleh ahli lain seperti Longeveed (dalam Willis, 2005 : 131) disebut sebagai kata hati pengganti. Yang mengandung makna hati yang terbentuk karena kasih sayang.

Di Kota Denpasar para remaja yang masih menjadi siswa memang memiliki pandangan yang berbedabeda terhadap perilaku terkait aktivitas agama sebagaimana hasil yang didapat bahwa :

"Lingkungan keluarga memang salah satu faktor yang mempengaruhi perilaku para remaja di Kota Denpasar. Para siswa yang berasal dari keluarga yang rendah pendidikan dan ekonomi cenderung mengalami perubahan perilaku terhadap aktivitas keagamaan dan bisa terjerumus pada kasus kenakalan remaja. Dalam pengamatan sehari -hari juga oleh kami siswa yang kurang mendapat perhatian di rumahnya cenderung menjadi remaja yang nakal."

Berdasarkan pada uraian data di atas dapat dikatakan bahwa faktor keluarga dapat menjadi faktor yang mendorong perubahan perilaku remaja Hindu terhadap aktivitas keagamaan di Kota Denpasar.

\section{Faktor Lingkungan Sosial \\ Masyarakat \\ Lingkungan sosial adalah}

lingkungan orang-orang yang berada di luar lingkungannya, teman-teman di sekeliling rumah atau di mana remaja sering berada atau berkumpul (Panuju, 1999: 73).

Faktor lingkungan sosial masyarakat dapat mempengaruhi perubahan prilaku remaja terhadap aktivitas keagamaan di Kota Denpasar Perubahan prilaku remaja dalam realita yang didapat di lapangan dalam uraian berikut :

Perubahan prilaku remaja terhadap aktivitas keagamaan sekarang cenderung ke arah ritual luar belum pada makna, para remaja sebagai siswa memang kalau diajak dalam kegiatan keagamaan seperti mejejaitan dan ikut menyelenggarakan kegiatan keagamaan yang semarak namun jika ditanyakan tentang inti hakekatnya dan makna, itu yang kurang dipahami hal ini karena pengaruh lingkungan sosial masyarakatnya.

\section{PENUTUP}

Remaja sebagai tulang punggung kehidupan berbangsa dan bernegara agar selalu mengisi diri dengan keterampilan-keterampilan yang 
cukup banyak untuk dapat memenangkan persaingan yang semakin ketat dewasa ini. Pada jaman globalisasi ini semua pihak termasuk di dalamnya para remaja sudah mulai tidak bisa menghindar dari era globalisasi yang cendrung individual, kapitalis, dan materialistis. Sesungguhnya era globalisasi tidak perlu dipandang sebagai suatu yang negatif dan ditakuti, namun akan banyak menuntut generasi muda untuk mengisi diri agar dapat memenangkan persaingan hidup yang semakin ketat kedepannya. Remaja yang malas, tidak mau berusaha dengan giat untuk mengisi dirinya maka dengan sendirinya akan tenggelam dalam dunia persaingan global. Era global menuntut sember daya manusia yang cerdas, cekatan, dan mampu bekerja dengan propesionalisme yang tinggi sehingga dapat menghasilkan dan membangun suatu peradaban yang berguna bagi masyarakat dalam arti yang lebih luas.

\section{Daftar Pustaka}

Aji, Mohamad, 2004. Psikologi Remaja Perkembangan Anak Didik, Jakarta PT Bumi Akasara.

Ali, Saifulah, H.A. 1977, Antara Filsafat dan Pendidikan, Surabaya, Usaha Nasional

Ariesandi. 2008. Rahasia Mendidik Anak Agar Sukses dan Bahagia. Jakarta: PT. Gramedia Pustaka Utama.

Baharudin, 2009. Pendidikan dan Psikologi Perkembangan, Jogjakarta, Ar-Ruzz Media.

Departemen Sosial RI. 1996. Pola Dasar Bidang Kesejahteraan Sosial. Jakarta : Balitbang Kesos.

Djaali, Prof. Dr, 2009. Psikologi
Pendidikan. Jakarta : Bumi Aksara.

Ferdinan. 2005. Menjadi Orang Tua Bijaksana. Yogyakarta : Tugu.

Haswari. 2003. Model Pengintegrasian

Pendidikan Budi Pekerti ke Dalam Pendidikan Agama. Jakarta : Depdiknas.

Hendarti Agustiani. 2006. Psikologi Perkembangan. Bandung : Refika Aditama.

Ihroni, T.O.2004. Bunga Rampai Sosiologi Keluarga. Jakarta : Yayasan Obor Indonesia.

Koentjaraningrat, 2002. Pengantar Ilmu Antropologi. Jakarta : Rienaka Cipta.

Oemar, Hamalik. 2008. Perencanaan Pengajaran Berdasarkan Pendekatan Sistem, Jakarta : Bumi Aksara.

Panut Panuju dan Ida Umami. 1999. Psikologi Remaja. Yogyakarta. PT. Tiara Wacana.

Soekanto, Soejono. 1986. Sosiologi Suatu Pengantar. Jakarta : CV. Rajawali.

Yusuf. 2008. Psikologi Perkembangan Anak \& Remaja. Bandung : PT. Remaja Rosdakarya. 